\title{
Factors Affecting the Career and Speciality Preferences of Dental Students in Trinidad and Tobago: A Cross-Sectional Survey
}

\author{
Trudee Hoyte ${ }^{1}$, Kevin Henry², Anne Kowlessar ${ }^{1}$, Anil Ali1 ${ }^{1}$ Adilah Mahabir ${ }^{1}$ \\ ${ }^{1}$ School of Dentistry, Department of Child Dental Health, The University of the West Indies, St. Augustine, Trinidad \\ ${ }^{2}$ School of Dentistry, Department of Oral Diseases, The University of the West Indies, St. Augustine, Trinidad \\ Email: trudee.hoyte@sta.uwi.edu
}

How to cite this paper: Hoyte, T., Henry, K., Kowlessar, A., Ali, A., \& Mahabir, A. (2021). Factors Affecting the Career and Speciality Preferences of Dental Students in Trinidad and Tobago: A Cross-Sectional Survey. Creative Education, 12, 1792-1804. https://doi.org/10.4236/ce.2021.128136

Received: July 6, 2021

Accepted: August 2, 2021

Published: August 5, 2021

Copyright (c) 2021 by author(s) and Scientific Research Publishing Inc. This work is licensed under the Creative Commons Attribution International License (CC BY 4.0).

http://creativecommons.org/licenses/by/4.0/

\begin{abstract}
Objective: The purpose of this study was 1) to identify the factors that affect dental students' decision to pursue specialisations and different career paths. 2) to identify the most common speciality of interest and factors that influence that decision. 3) to determine if there is a significant difference in factor selection by gender. Materials and Methods: An online cross-sectional self-administered questionnaire was formulated. The sample population consisted of clinical dental students and interns of The University of the West Indies. Participants were then asked about their plans after leaving dental school and questioned if they wish to specialise and the main reasons. Factors influencing their choices were assessed using a 5 point Likert scale. They were also asked about their preferred work sector. Results: Fifty-six dental students responded and this gave a response rate of $55.4 \%$. Males comprised $14.3 \%$ and females $85.7 \%$ of the sample. $80.4 \%$ of the respondents reported a desire to pursue a specialist career. The most preferred speciality was Aesthetic Dentistry $(n=12,21.4 \%)$ followed by respondents who preferred not to specialise $(n=11,19.6 \%)$ and then Paediatric Dentistry $(n=8,14.3 \%)$. Overall, participants reported personal preference, flexible work schedule and job security were the three most important factors for selecting a career path. Most participants preferred to work in the private sector. There was no association with gender and choosing a specialist career. Conclusion: This study shows the most desired career choices and specialities. There is a need to encourage students to steer towards general dentistry, the public sector and academia. The results show a baseline for national policies and possible postgraduate programmes of interest for this country.
\end{abstract}

\section{Keywords}

Dental Career, Dental Specialities, Dental Education, Student Motivations, 


\section{Introduction}

Dental students' career prospects have many determinants, one of which is the demographics of the population (Orenuga \& da Costa, 2006; Scarbecz \& Ross, 2007; Winter \& Butters, 1998). Dentistry is also affected by changes in politics, religion, community, economics and society (De Vries et al., 2008).

Weaver (Weaver, 1999) defined postgraduate dental education as "a personal choice to undertake additional education years after graduation or before starting practice". To provide high quality dental care for a population, there is a need for a dentist to pursue specialisation.

Studies have shown that most undergraduate dental students prefer to pursue postgraduate training (Stewart, Drummond, Carson, \& Hoad Reddick, 2005; Weaver, Haden, \& Valachovic, 2002). Several studies in the literature have investigated dental students' career choices (Crossley \& Mubarik, 2002; Karibe et al., 2009; Vigild \& Schwarz, 2001; Zadik, Gilad, \& Peretz, 1997). Zadik et al. (Zadik et al., 1997) reported that dental students emphasised eventual financial security and income. Helping people was low in priority to that sample of dental students. Moreover, the subject of altruistic reasons versus financial gain as reasons for specialising has been heavily debated in the literature (Crossley \& $\mathrm{Mu}$ barik, 2002; Karibe et al., 2009; Okwuje, Anderson, \& Valachovic, 2009; Vigild \& Schwarz, 2001; Zadik et al., 1997).

Worldwide more dental schools are being opened, and the dental workforce in most countries has increased.

Dental training in Trinidad and Tobago takes five years. This is followed by a 1-year internship for those wishing to be eligible to be part of the local dental workforce. This dental school has no postgraduate programmes, and therefore anyone who desires postgraduate training will have to do so at an international university. In recent times some postgraduate courses from these universities have become available via distance education. There has been no previous study to ascertain why and what factors influence students in this country to prefer a particular sector (private versus public) or even to opt to specialise. Some studies have reported that gender was a determinant in deciding speciality, stating that females were more likely to choose Paediatric Dentistry while males were more likely to choose Oral and Maxillofacial Surgery (Weaver, Chmar, Haden, \& Valachovic, 2005). Weaver et al. (Weaver et al., 2005) also reported that "enjoyment of providing care" was the primary reason for selecting a speciality. Noteworthy is that this study was conducted on students in the USA, where Oral and Maxillofacial Surgery, Paediatric Dentistry and Orthodontics were the most commonly offered postgraduate courses.

To help explain the characteristics of future personnel, demographic studies 
on dental students are needed (Tanalp, Ilguy, Dikbas, \& Oktay, 2012). The challenge for health care workforce planning is to strike a balance between dental needs and supply. The first step in policy making would be to have descriptive data on dental students. The dental school in Trinidad and Tobago needs to start postgraduate programmes, and needs versus supply must be the driving force for such a project. There must also be a striking balance between specialist and general dentist for proper workforce planning by the government to meet the country's health objectives.

The results of this study would help to counsel and mentor students about career pathways (Lee \& Ross, 2018).

The objectives of this study are:

- To identify the factors that influence dental students' decision to pursue specialisation.

- To ascertain how many students intend to specialise and the most common speciality of interest.

- To determine if there is a significant difference in postgraduate programme selection by gender.

\section{Materials and Methods}

\subsection{Study Site}

The University of the West Indies dental school is the only dental school in Trinidad and Tobago. The school opened in 1989. In 2021, its undergraduate pre-clinical and clinical students total 137 . The current interns total 20 dentists. The school graduates approximately 20 - 30 students per academic year.

\subsection{Approval}

Permission and ethical approval was obtained from The University of The West Indies Ethics Committee and Registrar's office (CREC-SA.0603/11/20). Informed consent was obtained from the dental students.

\subsection{Design}

An online cross-sectional self-administered questionnaire was formulated. The anonymised survey was administered via survey planet (Survey Planet LLC, Marini Del Ray, CA, USA) on 11th April 2021, followed by a reminder on the $25^{\text {th }}$ April 2021. The questionnaire was available for three weeks, and the window period for responses closed on 2nd May 2021. The sample population consisted of clinical dental students and interns of The University of the West Indies. Face validity was conducted by running a pilot on 11 dental students who were not part of the final survey. After these 11 participants made comments on the questions. The questionnaire was adjusted. The final sample size was 101 students. The survey was sent to students via the dental students' association.

The first page of the survey obtained consent from the participants. It also informed the participants that participation was voluntary and anonymous. The 
questionnaire consisted of 10 questions. The first part included sociodemographic data (gender, age, marital status, nationality, year of study, and asked if the participant had any children). Participants were then asked about their plans after leaving dental school and questioned if they wish to specialise. They were asked to indicate their first choice out of a list of 16 options along with the option of general dentistry. A 5 point Likert scale was used, and the questionnaire ascertained reasons for choosing general dentistry or a specialist field. The options were 1 not important, 2 slightly important, 3 moderately important, 4 very important, 5 extremely important. Participants were asked to rate which factors influenced their choice post-graduation. This again was assessed using the same 5 point Likert scale.

\subsection{Statistical Analysis}

The data was cleaned and imported into a statistical package SPSS (software package version 27, IBM, NY, USA). Descriptive analysis, Kendall's tau-b analysis and chi-square test were tabulated. Cronbach's alpha was used to assess the reliability of some of the questions.

\section{Results}

Fifty-six participants out of 101 responded, giving a response rate of $55.4 \%$. The demographic data of participants are shown in Table 1. Males comprised $14.3 \%$ $(\mathrm{n}=8)$ and females $85.7 \%(\mathrm{n}=48)$ of the participants. Almost half of respondents $51.8 \%(n=29)$ were from the 20 - 24 age range. Almost all of the respondents were single and nationals of Trinidad and Tobago, 92.9\% and $85.4 \%$ respectively. There was a larger percentage of female participants hence the larger percentage for each variable. A Kendall's tau-b analysis was done to check for association between the variables and gender. The analysis showed that all $p$-values were greater than 0.05 level of significance. Hence, we fail to reject the null hypothesis. Therefore, there exists no association between the variables listed in Table 1 and gender.

The most preferred speciality was Aesthetic Dentistry $(\mathrm{n}=12,21.4 \%)$ followed by respondents who did not wish to specialise $(n=11,19.6 \%)$; Paediatric Dentistry $(\mathrm{n}=8,14.3 \%)$; Orthodontics $(\mathrm{n}=5,8.9 \%)$ and Implantology $(\mathrm{n}=5$, $8.9 \%)$. When it came to second choice most persons stated they did not wish to specialise $(\mathrm{n}=13,23.2 \%)$, followed by Aesthetic Dentistry $(\mathrm{n}=8,14.3 \%)$ and Restorative Dentistry ( $\mathrm{n}=7,12.5 \%$ ) (Table 2$)$. No respondents chose Oral Medicine and Forensic Dentistry as any of their choices. Noteworthy is that $80.4 \%$ of respondents reported a desire to pursue a specialist career.

The mean scores of the responses for factors deciding choices of speciality/general dentistry are seen in Table 3.

Personal preference, flexible work schedules and job opportunities/security were the three most important factors in determining the choice of a potential career path. 
Table 1. Shows distribution of demographics by gender.

\begin{tabular}{|c|c|c|c|c|}
\hline & $\begin{array}{c}\text { Female } \\
\mathrm{n}=48 \\
\mathrm{n}(\%)\end{array}$ & $\begin{array}{l}\text { Male } \\
\mathrm{n}=8 \\
\mathrm{n}(\%)\end{array}$ & $\begin{array}{c}\text { Total } \\
\mathrm{n}=56 \\
\mathrm{n}(\%)\end{array}$ & Statistics \\
\hline \multicolumn{5}{|l|}{ Age } \\
\hline $20-24$ & $23(47.9 \%)$ & $6(75.0 \%)$ & $29(51.8 \%)$ & $p=0.304$ \\
\hline $25-30$ & $19(39.6 \%)$ & $1(12.5 \%)$ & $20(35.7 \%)$ & $\chi^{2}=2.380$ \\
\hline $31-35$ & $6(12.5 \%)$ & $1(12.5 \%)$ & $7(12.5 \%)$ & \\
\hline \multicolumn{5}{|l|}{ Marital status } \\
\hline Married & $3(6.3 \%)$ & $1(12.5 \%)$ & $4(7.1 \%)$ & $p=0.525$ \\
\hline Single & $45(93.8 \%)$ & $7(87.5 \%)$ & $52(92.9 \%)$ & $\chi^{2}=0.404$ \\
\hline \multicolumn{5}{|l|}{ Nationality } \\
\hline Trinidadian & $41(85.4 \%)$ & $7(87.5 \%)$ & $48(85.7 \%)$ & $p=0.876$ \\
\hline Other & $7(14.6 \%)$ & $1(12.5 \%)$ & $8(14.3 \%)$ & $\chi^{2}=0.024$ \\
\hline \multicolumn{5}{|l|}{ Year of Study } \\
\hline 2020 (Interns) & $18(37.5 \%)$ & $4(57.1 \%)$ & $22(40.0 \%)$ & $p=0.543$ \\
\hline 2021 & $15(31.3 \%)$ & $2(28.6 \%)$ & $17(30.9 \%)$ & $\chi^{2}=2.146$ \\
\hline 2022 & $10(20.8 \%)$ & $0(0.0 \%)$ & $10(18.2 \%)$ & \\
\hline 2023 & $5(10.4 \%)$ & $1(14.3 \%)$ & $6(10.9 \%)$ & \\
\hline \multicolumn{5}{|c|}{ Do you have any children? } \\
\hline No & $45(93.8 \%)$ & $8(100.0 \%)$ & $53(94.6 \%)$ & $p=0.467$ \\
\hline Yes & $3(6.3 \%)$ & $0(0.0 \%)$ & $3(5.4 \%)$ & $\chi^{2}=0.528$ \\
\hline
\end{tabular}

Table 2. Dental students' speciality/general dentistry preference.

\begin{tabular}{ccc}
\hline Future Options & $\begin{array}{c}\text { First Preference } \\
\mathbf{n}(\%)\end{array}$ & $\begin{array}{c}\text { Second Preference } \\
\mathbf{n}(\%)\end{array}$ \\
\hline Aesthetic Dentistry & $12(21.4)$ & $8(14.3)$ \\
Does not apply/I do not wish to specialize & $11(19.6)$ & $13(23.2)$ \\
Paediatric Dentistry & $8(14.3)$ & $5(8.9)$ \\
Implantology & $5(8.9)$ & $5(8.9)$ \\
Orthodontics & $5(8.9)$ & $6(10.7)$ \\
Endodontics & $4(7.1)$ & $6(10.7)$ \\
Dental and Maxillofacial Radiology & $2(3.6)$ & $0(0.0)$ \\
Oral Pathology & $2(3.6)$ & $2(3.6)$ \\
Prosthodontics & $2(3.6)$ & $3(5.4)$ \\
Restorative Dentistry & $2(3.6)$ & $7(12.5)$ \\
Oral and Maxillofacial Surgery & $1(1.8)$ & $0(0.0)$ \\
Periodontology & $1(1.8)$ & $0(0.0)$ \\
Special Needs Dentistry & $1(1.8)$ & $0(0.0)$ \\
Forensic Dentistry & $0(0.0)$ & $0(0.0)$ \\
Oral Medicine & $0(0.0)$ & $0(0.0)$ \\
Public Health & $0(0.0)$ & $1(1.8)$ \\
\hline
\end{tabular}


Table 3. Mean scores and the responses to the factors affecting speciality/general dentistry choices.

\begin{tabular}{|c|c|c|c|c|c|c|c|c|}
\hline Rank & Factor & Mean Score \pm SD & $\begin{array}{c}\text { Not } \\
\text { Important }\end{array}$ & $\begin{array}{l}\text { Slightly } \\
\text { important }\end{array}$ & $\begin{array}{c}\text { Moderately } \\
\text { important }\end{array}$ & $\begin{array}{c}\text { Very } \\
\text { Important }\end{array}$ & $\begin{array}{l}\text { Extremely } \\
\text { important }\end{array}$ & Missing \\
\hline 1 & Personal Preference & $4.25 \pm 0.858$ & $0(0.0)$ & $3(5.4)$ & $6(10.7)$ & $21(47.5)$ & $26(46.4)$ & \\
\hline 2 & Level of Patient satisfaction & $3.95 \pm 1.069$ & $1(1.8)$ & $6(10.7)$ & $9(16.1)$ & $19(33.9)$ & $21(37.5)$ & \\
\hline 3 & Level of renumeration & $3.71 \pm 0.936$ & $6(10.7)$ & $16(28.6)$ & $21(37.5)$ & $12(21.4)$ & $1(1.8)$ & \\
\hline 4 & Guaranteed Income/Benefits & $3.95 \pm 0.818$ & 0 & $2(3.6)$ & $14(25.0)$ & $25(44.6)$ & $15(26.8)$ & \\
\hline 5 & $\begin{array}{l}\text { Prestige and Reputation } \\
\text { associated with specialty }\end{array}$ & $2.88 \pm 1.096$ & $8(14.3)$ & $9(16.1)$ & $25(44.6)$ & $10(17.9)$ & $4(7.1)$ & \\
\hline 6 & Job Opportunities/Job Security & $4.21 \pm 0.909$ & $1(1.8)$ & $2(3.6)$ & $6(10.7)$ & $22(39.3)$ & $25(44.6)$ & \\
\hline 7 & Type of patient seen & $3.13 \pm 1.010$ & $5(8.9)$ & $6(10.7)$ & $26(46.4)$ & $15(26.8)$ & $4(7.1)$ & \\
\hline 8 & Family Commitments & $3.70 \pm 1.111$ & $3(5.4)$ & $5(8.9)$ & $12(21.4)$ & $22(39.3)$ & $14(25.0)$ & \\
\hline 9 & Predictable working hours & $4.05 \pm 0.862$ & 0 & $2(3.6)$ & $13(23.2)$ & $21(37.5)$ & $20(35.7)$ & \\
\hline 10 & Flexible work schedule & $4.16 \pm 0.826$ & 0 & $1(1.8)$ & $12(21.4)$ & $20(35.7)$ & $23(41.1)$ & \\
\hline 11 & Length of Programme Study & $3.71 \pm 1.031$ & $1(1.8)$ & $5(8.9)$ & $18(32.1)$ & $16(28.6)$ & $15(26.8)$ & $1(1.8)$ \\
\hline 12 & $\begin{array}{c}\text { Influence of } \\
\text { family/friends/colleagues }\end{array}$ & $2.39 \pm 1.155$ & $17(30.4)$ & $11(19.6)$ & $19(33.9)$ & $7(12.5)$ & $2(3.6)$ & \\
\hline 13 & $\begin{array}{c}\text { Interactions with specialized } \\
\text { dentists }\end{array}$ & $3.16 \pm 1.247$ & $8(14.3)$ & $7(12.5)$ & $17(30.4)$ & $16(28.6)$ & $8(14.3)$ & \\
\hline 14 & Simplicity of Specialty & $3.04 \pm 1.144$ & $5(8.9)$ & $14(25.0)$ & $17(30.4)$ & $14(25.0)$ & $6(10.7)$ & \\
\hline 15 & $\begin{array}{l}\text { Financial Assistance to Fund } \\
\text { Post-Graduate Specialization }\end{array}$ & $3.48 \pm 1.401$ & $8(14.3)$ & $6(10.7)$ & $10(17.9)$ & $15(26.8)$ & $17(30.4)$ & \\
\hline 16 & $\begin{array}{l}\text { Availability of Post-Graduate } \\
\text { Courses Locally }\end{array}$ & $3.02 \pm 1.581$ & $16(28.6)$ & $6(10.7)$ & $7(12.5)$ & $13(23.2)$ & $13(23.2)$ & $1(1.8)$ \\
\hline 17 & Perceived Saturation of Field & $3.67 \pm 1.187$ & $4(7.1)$ & $4(7.1)$ & $14(25.0)$ & $17(30.4)$ & $16(28.6)$ & $1(1.8)$ \\
\hline 18 & Preference for Public Sector & $2.59 \pm 1.345$ & $17(30.4)$ & $9(16.1)$ & $16(28.6)$ & $8(14.3)$ & $6(10.7)$ & \\
\hline 19 & Preference for Private Sector & $3.54 \pm 1.159$ & $4(7.1)$ & $5(8.9)$ & $17(30.4)$ & $17(30.4)$ & $13(23.2)$ & \\
\hline
\end{tabular}

Association between gender and specialty preference is shown in Figure 1. 20.8\% ( $n=10)$ of females selected Aesthetic Dentistry as their first choice. However, the majority would have chosen Does not apply/I do not wish to specialise ( $\mathrm{n}=11,22.9 \%)$. On the other hand, there was an even number of male participants $(\mathrm{n}=2,25 \%)$ selecting Aesthetic Dentistry, Implantology and Orthodontics. However, a Kendall's tau-b analysis was done to check for association between the choice to pursue postgraduate specialization by gender. The analysis resulted in a $p$-value, 0.281 . Hence, we fail to reject the null hypothesis. Therefore, there exist no association between the choice to purse postgraduate specialisation and gender.

The Cronbach's alpha was $\alpha=0.845$ for the 19 items affecting the choice in a potential post-graduate pathway.

Most of the respondents reported wanting to work in the private sector, $83.9 \%$ $(\mathrm{n}=47)$ and only $5.4 \%(\mathrm{n}=3)$ wanted to work in academia (Table 4$)$. 
Table 4. Preferences by work sector of dental students.

\begin{tabular}{ccc}
\hline Plan After graduating & Yes & No \\
\hline Academia & $3(5.4)$ & $53(94.6)$ \\
Private Sector & $47(83.9)$ & $9(16.1)$ \\
Public Sector & $20(35.7)$ & $36(64.3)$ \\
Other Career & $1(1.8)$ & $55(98.2)$ \\
\hline
\end{tabular}

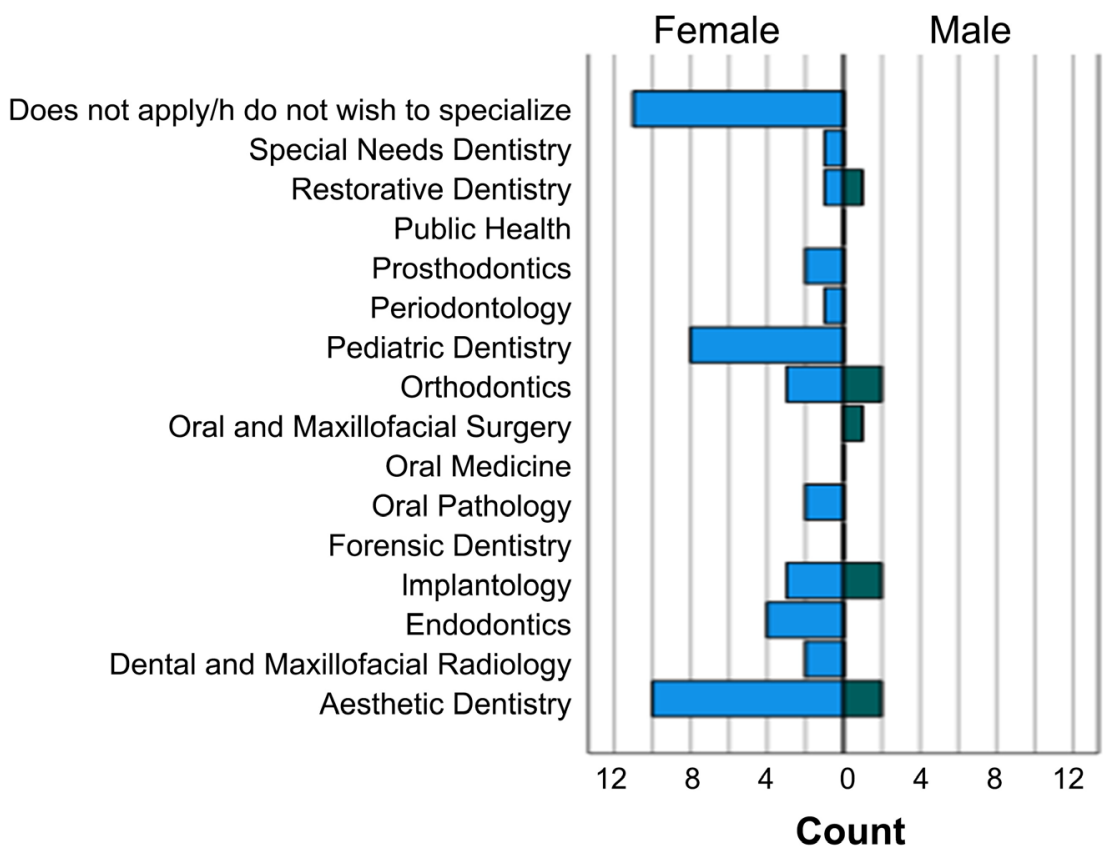

Figure 1. Distribution of speciality preference by gender.

\section{Discussion}

The clinical students and dental interns were the target group of this study. It was presumed that they would have been adequately exposed to the practical aspect of all disciplines, better cognizant of what each discipline entails and better able to make choices about career paths and specialisation. In this study, $80.4 \%$ of the respondents reported a desire to pursue a specialist career. This was similar to Fidele et al. (Fidele et al., 2018) who reported $81 \%$ of dental students in DR Congo, Puryer and Patel reported $71 \%$ of students at University of Bristol (Puryer \& Patel, 2016) and 86\% of respondents in a Turkish study (Tanalp et al., 2012) reported they preferred to pursue a speciality career. However this was much higher than reported by Japanese students (38.8\%) (Karibe et al., 2007) and Swedish students (37.2\%) (Puryer, Kostova, \& Kouznetsova, 2016). In both of these studies unlike our study, most students intended to stay in general practice. The Japanese students reported inheriting a family general dental practice as the main reason for most being steered into general practice. The Swedish students influence to specialise was the increased financial prospects of being a specialist which was similar to the reason given by the high number of students 
in DR Congo.

Our study found no association with gender and desire to pursue a postgraduate path. This is similar to Scarbecz and Ross (Scarbecz \& Ross, 2007) who found no gender differences in final year dental students who plan to pursue postgraduate education and other studies which had similar findings (Fisher, Wilson, \& Bartlett, 2007).

Personal preference, the main reason for postgraduate path selection in this study, was similar to Baharvand et al. (Baharvand, Moghaddam, Pouretemad, \& Alavi, 2011) findings in Iranian dental students and Lukandu (Lukandu, Koskei, \& Dimba, 2020) on Kenyan dental students. Personal preference as the main reason for choosing a speciality field is quite encouraging since it will lead to many enthusiastic postgraduate students and future specialists in that particular field. Also, it showed that these participants were mature and independent individuals not guided by parental or any other influence to make a decision. Conversely, other studies reported competence or talent in the field of specialisation as the major reason influencing dental students' choice of field for specialisation (Saeed, Jimenez, Howell, Karimbux, \& Sukotjo, 2008).

The second reason for choosing a speciality was the flexible work schedule and this could be a reflection of a larger proportion of this sample being female, most would likely in the future have families and therefore desire a flexible career. Scarbecz and Ross (Scarbecz \& Ross, 2002) reported in their study that both female and male respondents rated flexibility of career as the main reason for selection. Also, Saeed et al. stated that predictable work hours ranked high in his survey of dental students (Saeed et al., 2008). He also underscored like other authors the increasing need for a controllable lifestyle (Bland \& Isaacs, 2002; Dorsey, Jarjoura, \& Rutecki, 2003; Schwartz et al., 1990).

The desire for job security while third on this study list for choosing a postgraduate path, Cohen et al. showed that job security was the main reason (Cohen \& Coburn, 1977) for deciding to specialize.

In other studies, cost and length of training were the most significant barriers to specialisation in dentistry (Fisher et al., 2007; Puryer et al., 2016). Moreover, Canadian dental students reported being steered away from specialisation due to high student debt and expensive tuition fees (Karibe et al., 2007). This is in contrast to these students in Trinidad and Tobago where at the point in time this study was conducted tuition fees were either paid for by the government (Government Assisted Tuition Expenses programme) or students were on government scholarship. Very few students in this country have to pay tuition fees. Noteworthy there has been some career guidance offered at The University of The West Indies dental school, and Scarbecz and Ross stated that students are 5.93 times more likely to specialise if they receive encouragement (Scarbecz \& Ross, 2007). However educators at this institution need to ensure students are realistic about career paths since most will work in general practice (Lee \& Ross, 2018). During career guidance workshops educators should reiterate that general 
dentists are required to meet the needs of the larger population.

Due to low or non-existent student debt coupled with readily accessed scholarships, dental students in Trinidad and Tobago considered a speciality career. This economic reality would have influenced the response of participants in this survey. Thus reinforcing the concept that choosing of a speciality career in different countries is related to politics, economic realities and the period in time the study is conducted. Moreover, Baharvand et al. reported that dissimilarities in results from different countries could also be due to cultural differences (Baharvand et al., 2011).

Public health, Oral Medicine and Forensic Dentistry may be perceived as having limited employment opportunities and limited demand for services, so they were not the first choice of any of the participants in this study. However, interest in and exposure to these specialities can develop after graduation (Lee \& Ross, 2018).

Aesthetic Dentistry was the most preferred speciality in this study. This is similar to findings in another study (Halawany et al., 2017). Restorative Dentistry was the most preferred speciality in an institution in the U.K. (Fisher et al., 2007). Later the same institution, in the U.K reported Orthodontics as the most preferred speciality (Puryer et al., 2016). In Canada, the USA and Japan, Orthodontics was also the most preferred speciality (Karibe et al., 2007; Saeed et al., 2008). The preference for Aesthetic Dentistry in this study may be due to these participants thinking that there is a strong demand for Aesthetic Dentistry in private practice, and the potential for financial reward may make this speciality appealing. Scarbecz and Ross reported that a specialist earns a much higher income than a general dentist (Scarbecz \& Ross, 2002).

Paediatric Dentistry was the second most popular choice of participants followed by Orthodontics. Noteworthy, Dhima et al. (Dhima, Petropoulos, Han, Kinnunen, \& Wright, 2012) stated that Orthodontics had been ranked as high in improving patients and dentist quality of life and giving prosperity.

Male students in this sample also preferred Aesthetic Dentistry as their first preference, followed by Implantology and Orthodontics. This was in contrast to other studies that showed Oral and Maxillofacial Surgery as the preferred speciality among male dental students (Halawany, 2014; Weaver et al., 2005). This difference is understandable since flexible work schedule was listed as one of the most common reasons for selecting specialities in this study. Oral and Maxillofacial Surgery does not offer a flexible work schedule and comparatively has the longest training path, which could be another deterrent for females. Only females selected Paediatric Dentistry as their first choice in this study. This agrees with studies that concluded that Paediatric Dentistry is a female dominated speciality (Dhima et al., 2012; Katrova, 2004).

More participants preferred to work in the private than the public sector or academia. This is probably due to government jobs in the public sector having lower but standardised salaries and a higher patient workload than the private sector. This again is similar to findings by Baharvand et al. (Baharvand et al., 
2011). Thriving in an academic career requires applicants who are highly qualified with advanced degrees. This is probably one of the reasons for the small number of participants who desire to choose academia as a career. Rupp et al. (Rupp, Jones, \& Seale, 2006) also stated that dental students lacked information and knowledge pertaining to fundamental issues about a career in academia and even lacked teaching experience to make informed decisions. His study also stated that students are often advised of the burdens of academic life rather than the benefits so a career in private practice seems more advantageous.

This needs to be addressed by educators and they should advise on the benefits of an academic career in order for students to make informed decisions.

\section{Limitations}

As with all questionnaire-based surveys reporting bias might occur. Palqvist et al. (Palmqvist, Söderfeldt, \& Arnbjerg, 1991) stated that respondents could also choose socially acceptable responses when filling out online surveys. Asking students about plans may not directly correlate with what is actually pursued. A follow-up study in a few years is warranted.

\section{Conclusion}

A high percentage of dental students desired to pursue a speciality career. Aesthetic Dentistry is the most desired speciality. Personal preference was the most common reason for selecting a speciality and most respondents preferred to work in the private sector. There was no association between choosing to specialise and gender.

While in this study the results for specialisation are encouraging there is a need to encourage students to steer towards general dentistry, the public sector and academia.

The results give a baseline for national policies and possible postgraduate programmes of interest for this country.

\section{Conflicts of Interest}

The authors declare no conflicts of interest regarding the publication of this paper.

\section{References}

Baharvand, M., Moghaddam, E. J., Pouretemad, H., \& Alavi, K. (2011). Attitudes of Iranian Dental Students toward Their Future Careers: An Exploratory Study. Journal of Dental Education Journal of Dental Education, 75, 1489-1495. https://doi.org/10.1002/j.0022-0337.2011.75.11.tb05207.x

Bland, K. I., \& Isaacs, G. (2002). Contemporary Trends in Student Selection of Medical Specialties: The Potential Impact on General Surgery. JAMA Surgery, 137, 259-267. https://doi.org/10.1001/archsurg.137.3.259

Cohen, R., \& Coburn, D. (1977). Motivations for Studying Dentistry among First-Year Dental Students. Medical Education, 11, 139-150. 
https://doi.org/10.1111/j.1365-2923.1977.tb00578.x

Crossley, M. L., \& Mubarik, A. (2002). A Comparative Investigation of Dental and Medical Student's Motivation towards Career Choice. British Dental Journal, 193, 471-473. https://doi.org/10.1038/sj.bdj.4801599

De Vries, J., Murtomaa, H., Butler, M., Cherrett, H., Ferrillo, P., Ferro, M. B., Shanley, D. et al. (2008). The Global Network on Dental Education: A New Vision for IFDEA. European Journal of Dental Education, 12, 167-175. https://doi.org/10.1111/j.1600-0579.2007.00498.x

Dhima, M., Petropoulos, V. C., Han, R. K., Kinnunen, T., \& Wright, R. F. (2012). Dental Students' Perceptions of Dental Specialties and Factors Influencing Specialty and Career Choices. Journal of Dental Education, 76, 562-573. https://doi.org/10.1002/j.0022-0337.2012.76.5.tb05290.x

Dorsey, E. R., Jarjoura, D., \& Rutecki, G. W. (2003). Influence of Controllable Lifestyle on Recent Trends in Specialty Choice by US Medical Students. JAMA, 290, 1173-1178. https://doi.org/10.1001/jama.290.9.1173

Fidele, N. E., Kalala Kazadi, E., Mantshumba-Milolo, A., Mbuebo, M., Paul, S., Pierrot, K., Joseph, L. et al. (2018). The Pre and Final Year Dental Students' Attitudes, Perception towards Postgraduate Specialization in Kinshasa University-Dental Medicine Department/DR. Congo. Creative Education, 9, 1808-1817.

https://doi.org/10.4236/ce.2018.912131

Fisher, N. L., Wilson, R., \& Bartlett, D. (2007). The Perceived Barriers of Vocational Dental Practitioners in London to Specialisation. British Dental Journal, 203, 25-27. https://doi.org/10.1038/bdj.2007.779

Halawany, H. S. (2014). Career Motivations, Perceptions of the Future of Dentistry and Preferred Dental Specialties among Saudi Dental Students. Open Dentistry Journal, 8, 129-135. https://doi.org/10.2174/1874210601408010129

Halawany, H. S., Binassfour, A. S., AlHassan, W. K., Alhejaily, R. A., Al Maflehi, N., Jacob, V., \& Abraham, N. B. (2017). Dental Specialty, Career Preferences and Their Influencing Factors among Final Year Dental Students in Saudi Arabia. The Saudi Dental Journal, 29, 15-23. https://doi.org/10.1016/j.sdentj.2016.12.001

Karibe, H., Kawakami, T., Suzuki, A., Warita, S., Ogata, K., Aoyagi, K., Dahllöf, G. et al. (2009). Career Choice and Attitudes towards Dental Education amongst Dental Students in Japan and Sweden. European Journal of Dental Education, 13, 80-86. https://doi.org/10.1111/j.1600-0579.2008.00543.x

Karibe, H., Suzuki, A., Sekimoto, T., Srithavaj, M. L., Iamaroon, A., Warita, S., Nakahara, S. et al. (2007). Cross-Cultural Comparison of the Attitudes of Dental Students in Three Countries. Journal of Dental Education, 71, 1457-1466. https://doi.org/10.1002/j.0022-0337.2007.71.11.tb04417.x

Katrova, L. G. (2004). Gender Impact on the Socioprofessional Identification of Women Dentists in Bulgaria. Journal of Dental Education, 68, 19-22. https://doi.org/10.1002/j.0022-0337.2004.68.7_suppl.tb03810.x

Lee, Y., \& Ross, A. J. (2018). Projected Speciality Career Choices among Undergraduate Dental Students in Scotland. British Dental Journal, 224, 32-37. https://doi.org/10.1038/sj.bdj.2017.1002

Lukandu, O. M., Koskei, L. C., \& Dimba, E. O. (2020). Motivations for a Career in Dentistry among Dental Students and Dental Interns in Kenya. International Journal of Dentistry Journal, 2020, Article ID: 1017979. https://doi.org/10.1155/2020/1017979

Okwuje, I., Anderson, E., \& Valachovic, R. W. (2009). Annual ADEA Survey of Dental 
School Seniors: 2008 Graduating Class. Journal of Dental Education, 73, 1009-1032. https://doi.org/10.1002/j.0022-0337.2009.73.8.tb04790.x

Orenuga, O. O., \& da Costa, O. O. (2006). Characteristics and Study Motivation of Clinical Dental Students in Nigerian Universities. Journal of Dental Education, 70, 996-1003. https://doi.org/10.1002/j.0022-0337.2006.70.9.tb04171.x

Palmqvist, S., Söderfeldt, B., \& Arnbjerg, D. (1991). Self-Assessment of Dental Conditions: Validity of a Questionnaire. Community Dentistry and Oral Epidemiology, 19, 249-251. https://doi.org/10.1111/j.1600-0528.1991.tb00160.x

Puryer, J., \& Patel, A. (2016). The Career Intentions, Work-Life Balance and Retirement Plans of Dental Undergraduates at the University of Bristol. British Dental Journal, 220, 183-186. https://doi.org/10.1038/sj.bdj.2016.135

Puryer, J., Kostova, V., \& Kouznetsova, A. (2016). Final-Year Dental Undergraduate Attitudes towards Specialisation. Dentistry Journal, 4, 26. https://doi.org/10.3390/dj4030026

Rupp, J. K., Jones, D. L., \& Seale, N. S. (2006). Dental Students' Knowledge about Careers in Academic Dentistry. Journal of Dental Education, 70, 1051-1060. https://doi.org/10.1002/j.0022-0337.2006.70.10.tb04177.x

Saeed, S., Jimenez, M., Howell, H., Karimbux, N., \& Sukotjo, C. (2008). Which Factors Influence Students' Selection of Advanced Graduate Programs? One Institution's Experience. Journal of Dental Education, 72, 688-697. https://doi.org/10.1002/j.0022-0337.2008.72.6.tb04534.x

Scarbecz, M., \& Ross, J. A. (2002). Gender Differences in First-Year Dental Students' Motivation to Attend Dental School. Journal of Dental Education, 66, 952-961. https://doi.org/10.1002/j.0022-0337.2002.66.8.tb03564.x

Scarbecz, M., \& Ross, J. A. (2007). The Relationship between Gender and Postgraduate Aspirations among First- and Fourth-Year Students at Public Dental Schools: A Longitudinal Analysis. Journal of Dental Education, 71, 797-809. https://doi.org/10.1002/j.0022-0337.2007.71.6.tb04336.x

Schwartz, R. W., Haley, J. V., Williams, C., Jarecky, R. K., Strodel, W. E., Young, B., \& Griffen Jr., W. O. (1990). The Controllable Lifestyle Factor and Students' Attitudes about Specialty Selection. Academic Medicine, 65, 207-210. https://doi.org/10.1097/00001888-199003000-00016

Stewart, F. M., Drummond, J. R., Carson, L., \& Hoad Reddick, G. (2005). A Survey of Dental School Applicants' Career Intentions and the Balance with Family Life. British Dental Journal, 198, 713-717. https://doi.org/10.1038/sj.bdj.4812391

Tanalp, J., Ilguy, D., Dikbas, I., \& Oktay, I. (2012). Demographic Profile and Future Expectations of Students Enrolled in a Turkish Private Dental School. Journal of Dental Education, 76, 800-809. https://doi.org/10.1002/j.0022-0337.2012.76.6.tb05316.x

Vigild, M., \& Schwarz, E. (2001). Characteristics and Study Motivation of Danish Dental Students in a Longitudinal Perspective. European Journal of Dental Education, 5, 127-133. https://doi.org/10.1034/j.1600-0579.2001.050306.x

Weaver, R. G. (1999). Continued Formal Dental Education or I Would Like More. Journal of the American College of Dentists, 66, 31-35.

Weaver, R. G., Chmar, J. E., Haden, N. K., \& Valachovic, R. W. (2005). Annual ADEA Survey of Dental School Seniors: 2004 Graduating Class. Journal of Dental Education, 69, 595-619. https://doi.org/10.1002/j.0022-0337.2005.69.5.tb03945.x

Weaver, R. G., Haden, N. K., \& Valachovic, R. W. (2002). Annual ADEA Survey of Dental School Seniors: 2002 Graduating Class. Journal of Dental Education, 66, 1388-1404. 
https://doi.org/10.1002/j.0022-0337.2002.66.12.tb03613.x

Winter, P. A., \& Butters, J. M. (1998). An Investigation of Dental Student Practice Preferences. Journal of Dental Education, 62, 565-572. https://doi.org/10.1002/j.0022-0337.1998.62.8.tb03215.x

Zadik, D., Gilad, R., \& Peretz, B. (1997). Choice of Dentistry as a Career and Perception of the Profession. Journal of Dental Education, 61, 813-816.

https://doi.org/10.1002/j.0022-0337.1997.61.10.tb03164.x 